Available online:

http://journal.imla.or.id/index.php/arabi

Arabi : Journal of Arabic Studies, 5 (2), 2020, 201-215

DOI: http://dx.doi.org/10.24865/ajas.v5i2.206

\title{
PROBLEMATIKA PENERAPAN PEMBELAJARAN MAHFÛZHAT BAHASA ARAB BAGI MAHASISWA
}

\author{
Maman Abdurahman, Masor, Hikmah Maulani, Ade Kartini \\ Universitas Pendidikan Indonesia, Bandung, Indonesia \\ E-mail : mamanabdurrahman@upi.edu
}

\begin{abstract}
Characteristic of mahfühat is using of high register and contain cultural content and norms. That is bring own problems into student from memorizing procces, understanding a meaning and practicing. The goals of this study aims to describe and to provide a solution problematic that it has related with mahfuzhat learning. This research uses a case study approach, by observing field phenomena. As for the research subjects, namely students of the 1st semester of the Arabic Language Education Department. The data were collected using observation, interviews, and documentation, then the data analysis used was data display, data reduction and triangulation. The research findings show that the problem of competency aspects is due to aspects of vocabulary, rules and differences in several elements and characteristics between Arabic and Indonesian, the lack of time for practice, nonlinguistic problems due to internal and external factors of the learners. The solutions include increasing the components and implementing learning as well as strengthening the motivation and self-confidence of learner.
\end{abstract}

Keywords: problematic, Arabic language, Arabic learning, mahfüzhat

\begin{abstract}
Abstrak
Ciri khusus mahfüzhat adalah penggunaan register tinggi serta mengandung muatan budaya dan norma, hal tersebut menjadi kendala tersendiri bagi mahasiswa mulai dari tahap menghafal, memahami dan mempraktikan dalam proses berbahasa. Tujuan penelitian ini adalah mengkaji serta memberi solusi terkait masalah-masalah serta problematika pembelajaran mahfüzhat. Penelitian ini dilaksanakan melalui pendekatan studi kasus, yakni mengamati fenomena lapangan. Subjek penelitian ini adalah mahasiswa semester 1 Departemen Pendidikan Bahasa Arab. Pengumpulan data dilakukan dengan observasi, wawancara, dan dokumentasi. Adapun analisis data yang digunakan adalah display data, reduksi data dan triangulasi. Hasil penelitian menjelaskan bahwa masalah aspek kompetensi disebabkan oleh aspek kosakata, aturan dan perbedaan beberapa elemen dan karakteristik antara bahasa Arab dan bahasa Indonesia, kurangnya waktu untuk latihan, masalah non-linguistik karena faktor internal dan eksternal peserta didik. Solusinya antara lain peningkatan komponen dan pelaksanaan pembelajaran serta penguatan motivasi dan kepercayaan diri peserta didik.
\end{abstract}

Kata Kunci: problematika, bahasa Arab, pembelajaran, mahfüzhat 


\section{Arabi : Journal of Arabic Studies}

\section{Pendahuluan}

Bahasa diartikan sebagai alat penghubung yang terjalin antara manusia dengan manusia, manusia dengan masyarakat, pula masyarakat dengan masyarakat lainnya (Nandang dan Sanusi, 2019: 166). Mahfüzhat atau proverb memuat beberapa hal yakni pepatah, peribahasa. Proverb juga salah satu simbol dari nilai-nilai budaya bahasa target. Othoman (2013: 1) menambahkan bahwa penggunaan proverb biasanya register tinggi. Hal tersebut sejalan dengn karakteristik budaya Arab yang memiliki budaya komunikasi tingkat tinggi. Penggunaan mahfüzhat bukan hanya pada teksteks keagamaan, namun digunakan dalam konteks yang sangat luas meliputi media masa, media sosial, film seri, film dokumenter.

Akar kata mahfüzhat yaitu dari kata hafidza, sebagai bentuk pasif partisipasif dengan makna sesuatu yang hafal. Mahfüzhat terdiri dari peribahasa, perumpamaan serta idiom. lebih spesifik, komponen isi mahfüzhat yaitu kelompok kata atau kalimat yang tetap susunannya, yang bisanyanya mengiaskan maksud-maksud tertentu, atau sebuah kalimat yang mengandung ungkapan padat, berisi perbandingan, perumpaan, nasihat prinsip hidup atau aturan tingkah (KBBI, 2008). Pada prinsipnya, mahfüzhat mengandung beberpa aspek seperti tradisi budaya bahasa target (Arab), budaya, nilai-nilai masyarakat yang dituangkan dalam bentuk kalimat (Othoman, 2013: 41). Penyajian dengan bahasa register tinggi, sehingga hal ini berdampak pada kesulitan mahasiswa dalam memahami mahfüzhat.

Beberapa ahli seperti Moore dalam (Othoman 2013: 43) berpendapat bahwa kemunculan mahfühat atau proverb merupakan suatu prinsip hidup yang muncul dari persepsi umum masyarakat bahkan dijadikan sebuah dasar kebenaran. Dari batasan tersebut, diketahui bahwa mahfüzhat adalah peribahasa atau kelompok kata yang memuat maksud, nilai nilai budaya dan norma yang dituangkan dalam beberapa kata atau kalimat.

Terkait pemahaman mahfüzhat, maka sejatinya dibutuhkan pengetahuan tentang bahasa target baik terhadap aspek mikro maupun makro. Selain itu, dimensi pembelajaran bahasa kedua khususnya bahasa Arab bukan hanya sekedar mempelajari aspek empat kemahiran berbahasa yaitu menyimak, berbicara, membaca dan menulis dalam bahasa target, melainkan keterpahaman akan budaya bahasa target sangat diperlukan (Sheren, M.S 2008: 1).

Namun, praktik pembelajaran bahasa asing masih menekankan pada skala mikro. Seperti, morfologi, sintaksis dan semantik serta mengkaji gaya bahasa tanpa mengaitkan dengan budaya bahasa target. Serta minimnya buku ajar yang mengkaji secra khusus mengenai tentang mahfüzhat atau proverb. Hal ini berdampak pada rendahnya pemahaman pembelajar memahami mahfühat yang sangat terkait dengan nilai-nilai budaya bahasa target. Hal ini juga berdampak pada rendahnya kualitas lulusan lembaga penyelenggara bidang bahasa Arab dalam memahami mahfüzhat beregister tinggi.

Pada kenyataan lapangannya, seandainya bahasa asing yang dipelajarinya itu memiliki lebih banyak fonem-fonem yang tidak dimiliki oleh bahasa pertama, maka kesulitan yang timbul secara umum adalah kesulitan dalam pelafalan fonem-fonem bahasa kedua atau bahasa asing yang dipelajari tersebut. Kesulitan ini terjadi karena adanya perbedaan fonem-fonem kedua bahasa tersebut, baik dari sisi cara maupun posisi artikulasi. Adapun yang dimaksud kesulitan yang muncul itu yaitu berupa kesalahan pelafalan fonem-fonem bahasa kedua/asing yang dipelajari yang kemudian membawa dampak yang sangat fatal jika tidak diajarkan dengan baik kepada pelajar bahasa asing tersebut (Sanusi, Y. B, 2005: 2).

Selanjutnya penjelasan tentang dampak atau akibat dari kesalahan pelafalan fonem-fonem bahasa kedua/asing itu selanjutnya akan membawa ke arah keliruan makna. Semisal, kesalahan pelafalan yang dilakukan oleh para pembelajar bahasa kedua atau bahasa asing akan membingungkan lawan bicaranya khususnya lawan bicara penutur asli. Dan perlu diperhatikan, kesalahan makna dan kesalahan interpretasi ini mengakibatkan komunikasi tidak dapat berjalan dengan baik (Sanusi, Y. B, 2005: 2; Emil, F.J. 1981: 125). 


\section{Arabi : Journal of Arabic Studies}

Selain hal tersebut, faktor daya hafal atau daya ingat menjadi salah satu pertimbangan. ingatan didefinisikan sebagai kecakapan untuk menerima, menyimpan, dan memproduksi kesankesan. Terkait dengan ingatan yang mempunyai fungsi tersebut di atas maka belajar memerlukan metode agar pelajaran yang dipelajari atau yang dihafal dapat diproduksi kembali. Sampai akhirnya memperoleh kualitas hafalan yang sempurna (Gade, 2014: 422).

Terjait siasat teknik pengajarannya, melatih hafalan yaitu dengan metode pengulangan. Mengulang-ulang yang dibaca dengan tentunya didampingi guru akan jauh lebih efektif (Supriono dan Rusdiani, 2019:61). Maka dengan demikian, dalam pelaksanaannya pembelajaran memerlukan pendekatan sesuai dengan kondisi kelas. Pendekatan pembelajaran yaitu sebuah asumsi yang dianut untuk mencapai tujuan pembelajaran. Pendekatan pembelajaran sangatlah penting sebelum menentukan metode, strategi ataupun teknik bahkan sampai evaluasi yang akan digunakan dalam pembelajaran tersebut (Faiqah, 2017: 71).

Setiap siswa memiliki kemampuan yang berbeda, begitupun kemampuan memahami konsepkonsep pembelajaran. Kondisi ini dapat menjadikan mereka memiliki perbedaan pendapat dalam menyelesaikan suatu permasalahan. Dengan asumsi jik mereka semakin menguasai suatu konsep dalam pembelajaran, maka diharapkan pemecahan suatu masalah pembelajaran menjadi semakin mudah, dan hasil belajar menjadi lebih baik (Anzar dan Mardhatillah, 2017:54). Dan kemudian, salah satu konsep pembelajaran tersebut yaitu mahfüzhat.

Menyinggung soal model pembelajaran, adapun model pembelajaran haruslah mengacu pada pendekatan pembelajaran yang digunakan yaitu dengan meliputi tujuan pengajaran, kegiatan pembelajaran, lingkungan pembelajaran serta bentuk pengelolaan kelas (Rahmawati dan Laila, 2019: 59-60).

Pembelajaran bahasa merupakan sebuah aktivitas dan kegiatan terprogram dan terencana yang menyediakan fasilitas dan kesempatan yang memungkinkan siswa mengembangkan potensi berbahasa dan keterampilannya melalui aktivitas tersebut (Tajuddin, 2017: 202)

Pembelajaran bahasa asing khususnya bahasa Arab yang dipelajari di sekolah serta di pesantren lebih cenderung menggunakan dan menitikberatkan model pembelajaran bahasa secara formal. Hal ini disebabkan karena banyak aspek yang terlibat dalam kegiatan tersebut, seperti guru, media, kurukulim, bahan ajar, dan instrumen yang lainnya. Aspek-aspek tersebut memiliki pengaruh terhadap kecepatan dan keberhasilan belajar bahasa kedua (bahasa Arab) karena berbagai faktor juga variabel yang telah disiapkan dan direncanakan terlebih dahulu (Chaer, 2009: 252). Yang jelas, penyajian formal pembelajaran merupakan rekayasa untuk mencapai kompetensi yang diharapkan yang terjadi di lingkungan sekolah, sedangkan non-formal atau alami belajar bahasa di tempat atau negara penutur bahasa tersebut, dan bisa dikatakana total immersion.

Atas dasar alasan-alasan tersebut, penulis tertarik untuk meneliti problematika pembelajaran mahfüzhat. Berdasarkan hasil pengamatan penulis, menemukan bahwa mahasiswa jurusan Departemen Penidikan bahasa Arab FPBS UPI memiliki latar pendidikan dan penguasaan bahasa yang beragam. Sebagian mereka sudah mempelajari mahfüzhat di pondok pesantren meskipun sebatas menghapal dan memahami makna secara sepintas. Sebagian lagi mempelajari mahfüzhat di Madrasah Aliyah Negeri atau Swasta (MAN/MAS) tetapi tidak mendalam. Bahkan diantara mereka, terdapat mahasiswa yang belum pernah mempelajari karena mereka belajar di Sekolah Menengah Umum (SMU). Sehingga, dalam satu kelas terdapat tiga kelompok mahasiswa yang memiliki permasalahan belajar dalam hal menghafal, lebih khusus dalam mata kuliah mahfüzhat. Kelompok pertama, merasa jenuh mempelajari, kelompok kedua merasa jenuh dan sedikit kesulitan, sedangkan kelompok terakhir merasakan kesulitan yang lebih dari kelompok pertama dan kedua. Untuk mengatasi ketiga permasalahan tersebut, penulis menganggap perlu untuk mengkaji problematika yang dihadapi mahasiswa sehingga diharapkan akan tercipta proses pembelajaran yang lebih menyenangkan dan menambah motivasi belajar mahasiswa.

Salah satu motivasi yang disbeutkan yaitu terkait pemahaman Alquran. Dijelaskan bahwa Alquran diturunkan dalam bahasa Arab, dengan demikian maka diasumsikan bahwa untuk 


\section{Arabi : Journal of Arabic Studies}

membaca, memahami dan menelaah ayat-ayat Alquran diperlukan keahlian dalam bahasa Arab (Vadhillah, S, 2016: 50). Begitu pun dalam mengkaji bidang ilmu lainnya, para pembelajar diharuskan menguasai bahasa Arab sebagai elemen dan komponen dasar bagi penguasaan ilmu pengetahuan di tahap berikutnya (Hizbullah dan Mardiah, 2014: 190).

Penjelasan terakit bahasa Arab, tidak seidkit yang berpandangan bahwa bahasa Arab adalah bahasa agama, hal ini karena bahasa arab dipandang sebagai alat untuk mempelajari dan memahami teks atau naskah yang berbahasa Arab. Sebagian lainnya berpandangan bahwa belajar bahasa Arab merupakan belajar bahasa ilmu pengetahuan Islam. Pandangan ini juga tidak salah, karena pada dasaranya ilmu-ilmu Islam memiliki literatur referensi berbahasa Arab. Sebagian lainnya berpandangan bahwa belajar bahasa Arab adalah belajar berbahasa secara keseluruhan (Kosim, et al, 2020: 2)

Namun, berdasar pada teoretis, permasalahan pembelajaran bahasa Arab terbagi menjadi dua yaitu pertama, permasalahan kebahasaaan dan kedua, permasalahan non kebahasaan (Fahrurrozi, 2014:162). Berangkat dari penjelasan di atas, maka disimpulkan fokus penelitian ini adalah mengkaji tentang problematika pembelajaran mahfüzhat yang terkait dengan kesulitan mahasiswa dalam menggunakan dan memahami mahfüzhat, problem non kebahasaan, serta solusi yang dapat dilakukan untuk mengatasi kesulitan dalam memahami mahfüzhat serta mengaplikasikan atau menggunakannya.

\section{Metode}

Dewasa ini, metodologi pembelajaran masih menimbulkan banyak masalah yang belum tuntas terselesaikan (Wahida, 2017: 46). Maka dari itu, inovasi terus diupayakan dan dan dilakukan. Dalam penelitian ini, arah masalah berfokus pada indentifikasi dan penemuan solusi tentang problematika pembelajaran mahfüzhat. Subjek penelitian ini adalah mahasiswa Universitas Pendidikan Indonesia yang mengikuti mata kuliah mahfüzhat tahun akademik 2017/2018 dengan jumlah responden yakni 40 orang mahasiswa.

Penelitian ini memilih metode deskriptif kualitatif dengan pendekatan naturalistik. Metode ini digunakan mengkaji kondisi alamiah serta deskripsi secara nyata tentang permasalahan juga solusi dalam pembelajaran mahfüzhat. Lebih khusus, strategi penelitian yang digunakan yaitu studi kasus terpancang (embedded case study) karena permasalah atau fokus penelitian sudah ditentukan terlebih dahulu sebelum melaksankan penelitian di lapangan.

Secara skematis, alur kerangka pemikiran penelitian ini adalah seperti nampak dalam gambar berikut ini:

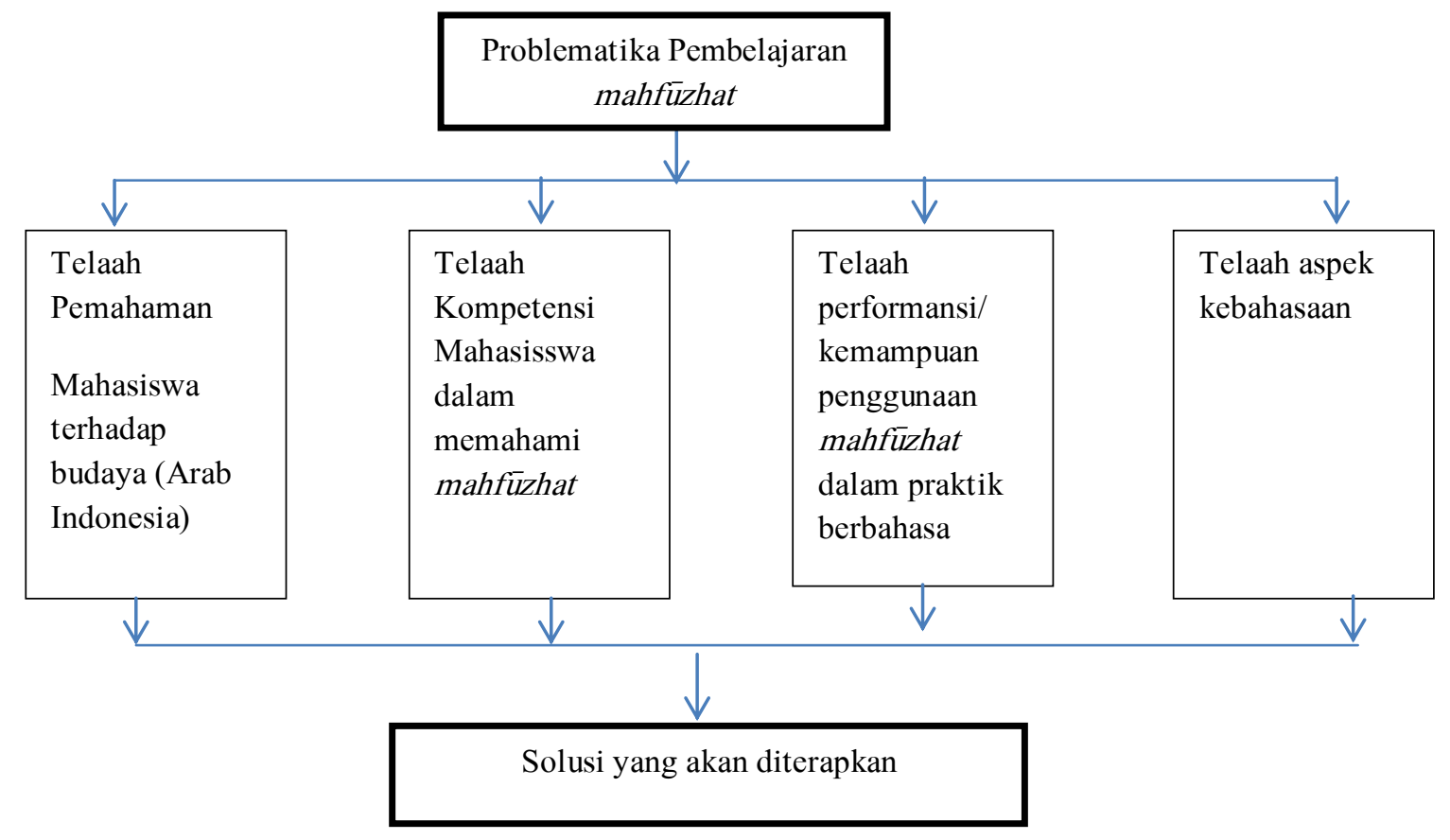

Vol. 5 No. 2 | 204-215

Copyright (C) 2020 | ARABI | p-ISSN 2548-6616 | e-ISSN 2548-6624 
Teknik pengumpulan data yang digunakan meliputi kajian pustaka yakni pengumpulan data berupa teori yang berhubungan dengan bahasan penelitian melalui buku. Observasi langsung cara mahasiswa dan tingkah laku mereka selama mengikuti proses pembelajaran, dilakukan untuk mengumpulkan data pada penelitian pendahuluan dan praktik berbahasa. Penyebaran angket terbuka atau open respon questioner diberikan kepada mahasiswa untuk menjaring pengalaman dan problem yang dialami mahasiswa ketika mempelajari mahfüzhat. Wawancara terhadap mahasiswa dan pengajar untuk verifikasi data.

\section{Hasil Penelitian dan Pembahasan}

\section{Kesulitan dan hambatan pada aspek kebahasaan untuk memahami mahfüzhat}

Berdasarkan penelusuran kuesioner, terjaring beberapa kendala dalam mempelajari bahasa Arab baik faktor linguistik dan non linguistik. Adapun kesulitan aspek kebahasaan yaitu (1) aspek kompetensi seperti memahami kalimat, sulit menghafal karena jarang digunakan, sulit memahami makna, pembendaharaan kosakata minim; (2) aspek performansi seperti selain berkomunikasi, menyusun kalimat, belum terbiasa, sulit menterjemah, membuat kalimat dari uslub uslub, kaku saat berbicara, sulit berbicara dengaan penutur asli dan membaca teks bahasa Arab.

Terdapat dua kemampuan berbahasa yang ingin dicapai, yaitu kemampuan aktif reseptif dan kemampuan aktif produktif. Fahrurrozi dan Mahyuddin menjabarkan(2012: 76), bahwa yang dimaksud dengan kemampuan berbahasa aktif reseptif adalah kemampuan untuk secara aktif memahami makna pembicaraan atau tulisan orang lain. Sedangkan kemampuan berbahasa aktif produktif adalah kemampuan untuk menggunakan bahasa sebagai penyampaian ide, gagasan, informasi atau perasaan dan sebagainya, baik secara lisan maupun tulisan.

Keterampilan berbahasa diantaranya adalah keterampilan menyimak, keterampilan membaca, sedangkan kemampuan aktif produktif diantaranya keterampilan berbicara dan keterampilan menulis. Berdasarkan medium komunikasinya, keterampilan berbahasa dapat dibedakan atas keterampilan berbahasa lisan dan keterampilan berbahasa tulis. Keterampilan berbahasa lisan memiliki dua aspek, yakni menyimak dan berbicara. selanjutnya keterampilan berbahasa tulis memiliki dua aspek, yakni membaca dan menulis (Sudaryat, 2015: 175).

Terkait dengan aspek (1) dan (2) sebagaimana diungkapkan oleh Mar'at, (2005: 94-96) dan Chaer, A. (2009: 250-254) waktu yang digunakan atau kesempatan untuk berbahasa relatif kurang, atau lingkungan bahasa sama sekali tidak ada. Kemudian perbedaan karakteristik bahasa Arab cukup mempengaruhi serta menjadi kendala dalam pembelajaran bahasa Arab. Bahasa Arab merupakan rumpun bahasa Semit yang memiliki perbedaan karakteristik dengan bahasa Indonesia atau bahasa daerah lainnya di Indonesia (Azhar, M, 2005:52).

Baik pada tingkap memahami atau penerjemahan mahfüzhat harus didasarkan pada budaya Arab. Maka, pemahaman yang baik terhadap budaya kedua bahasa (Indonesia dan Arab) sangat diperlukan. Dalam konteks penerjemahan, Nida dalam (Omari, J. 2008: 33) memberikan empat aspek pertimbangan yakni 1) ekologi, 2) material, 3) religious culture, 4) sosial culture, 5) linguistic culture.

a) Aspek ekologi mencakup salah satu aspek yang digambarkan dalam kategori yang mengacu pada binatang, tumbuhan, flora-fauna, cuaca, topografi lingkungan serta beberapa hal yang turut mempengaruhi terbentukknya mahfüzhat. Ekologi tempat berpijaknya rasa seperti penomena lingkungan atau lebih spesifiknya dimana bahasa itu digunakan, serta dampak dari bagaimana orang dan reaksi dari yang lainnya (Omari, J. 2008: 31).

b) Selanjutnya, aspek material budaya (material culture) mengacu pada berbagai jenis makanan, pakaian, rumah, kota, dan jenis transportasi.

c) Budaya mencakup aspek-aspek non-abstrak yang turut mempengaruhi kehidupan manusia. Hal ini mencakup pada jenis pakaian yang lazim serta yang tidak, jenis makanan yang khas atau bahkan dilarang. 


\section{Arabi : Journal of Arabic Studies}

d) Budaya sosial (sosial culture), aspek ini mencakup seluruh area dalam hubungan keluarga, norma, dan tradisi.

e) Religious culture, mengacu pada ukuran agama budaya, sekaligus menjadi problem tersendiri dalam memahami dan menterjemahkan mahfüzhat.

f) Budaya bahasa (linguistik culture), mengacu pada perbedaan fitur-fitur antara dua bahasa (Arab-Indonesia) khusunya. Perbedaan fitur dan karakteristik mengacu pada gaya, perbedaan kosakata, atau aspek sintaksis-semantis. Nida dalam (Omari, J. 2008: 36) menjelaskan problem budaya dalam memahami dan menterjemahkan perbedaan karakteristik pada keudua bahasa.

Berdasarkan pernyataan di atas merupakan beberapa hal yang perlu dipertimbang-kan dalam memahami sebuah mahfüzhat, yakni aspek makro yang menjadi latar disusunnya sebuah peribahasa.

Maka, dapat disimpulkan bahwa problem pada aspek performansi disebabkan oleh minimnya waktu atau intensitas untuk praktik berbahasa seperti minimnya intesitas waktu praktik empat kemahiran berbahasa, penggunaan idiom dan menterjemah. Hal ini diperkuat oleh problem pada aspek kompetensi baik aspek kosakata, kaidah serta perbedaan beberapa unsur dan karakteristik antara bahasa Arab dan bahasa Indonesia.

\section{Problematika penggunaan mahfühhat dalam praktik berbahasa}

Di dalam pembelajaran bahasa, ada dua kemampuan berbahasa yang ingin dicapai, yaitu kemampuan aktif reseptif dan kemampuan aktif produktuf. Menurut Fahrurrozi dan Mahyuddin (2012: 76), yang dimaksud dengan kemampuan berbahasa aktif reseptif yaitu kemampuan dengan sikap aktif memahami makna pembicaraan atau tulisan orang lain. Sedangkan kemampuan berbahasa aktif produktif yaitu kemampuan untuk menggunakan bahasa sebagai penyampaian ide, gagasan, informasi atau perasaan dan sebagainya, baik secara lisan maupun tulisan.

Selanjutnya keterampilan berbahasa dinataranya keterampilan menyimak, keterampilan membaca, sedangkan yang termasuk ke dalam kemampuan aktif produktif adalah keterampilan berbicara dan keterampilan menulis. Secara sifat medium komunikasinya, keterampilan berbahasa dapat dibedakan atas keterampilan berbahasa lisan dan keterampilan berbahasa tulis. Keterampilan berbahasa lisan memiliki dua aspek, yakni menyimak dan berbicara. Sedangkanketerampilan berbahasa tulis memiliki dua aspek, yakni membaca dan menulis (Sudaryat, 2015: 175).

\section{a. Problem Berbicara dan Mendengar mahfüzhat}

Adapun kendala pada kegiatan berbahasa mendengar dan berbicara meliputi aspek linguistik dan aspek non linguistik. Pertama, faktor lingusitik meliputi lemahnya mahasiswa pada bidang (1) fonologi, yakni kurang terbisasa mendengar dan menuturkan pelafalan penutur sejati; (2) semantik, yakni pembendaharaan kosakata yang minim berdampak pada pemahaman makna baik fusha dan amiyah. Adapun faktor non-kebahasaan kurangnya percaya diri dan belum terbiasa. Adapun upaya yang dilakukan dalam meningkatkan kegiatan berbahasa secara aktif yaitu melalui pembendaharaan kosakata serta fokus dalam mendengat tuturan. Hal tersebut diperkuat kembali temuan dari penelusuran kuesioner diketahui bahwa $(88,10 \%)$ mahasiswa memiliki kendala dalam mendengar dan berbicara bahasa Arab, dan (11,90\%) menyatakan tidak mengalami kendala. Namun problem tersebut merupakan dari minimnya motivasi dalam kemahiran mendengar. 
Bagan 1. Kesulitan praktik penggunaan mahfüzhat saat Mendengar dan Berbicara

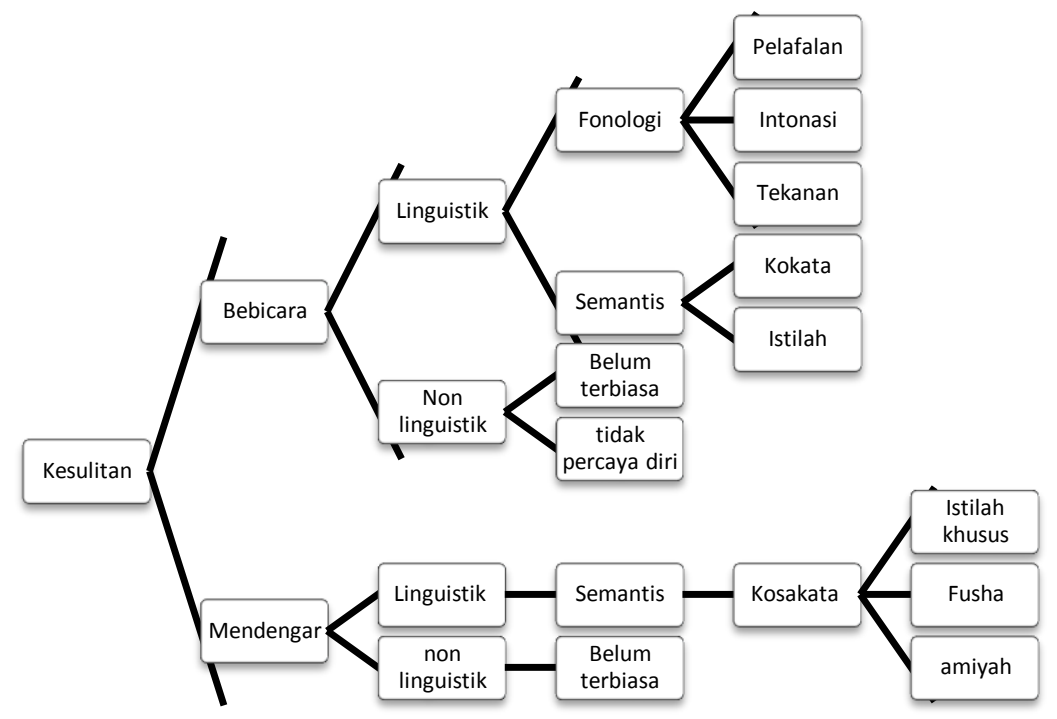

Jenis kesulitan yang terjadi dalam aspek keterampilan ini adalah siswa mengalami kesulitan dalam menyimak teks bahasa Arab. Indikator kesulitan yang dihadapi siswa terbanyak adalah kesulitan dalam mengingat detil dan urutan dari teks yang disimak, kemudian jenis kesulitan lainnya yaitu dalam mengungkapkan ide pokok, kesulitan dalam membuat kesimpulan isi teks, dan kesulitan dalam mengungkapkan komentar dan pemberian penilaian terhadap teks bahasa Arab yang disimak (Nurhidayati, 2004: 89). Aspek linguistik yang menjadi penyebab kesulitan terbanyak dalam menyimak adalah aspek keterbatasan kosa kata, sedang aspek nonlinguistik yang menjadi penyebab kesulitan terbanyak adalah aspek motivasi dan minat, yang disebabkan faktor eksteren yaitu aspek metode mengajar guru, aspek media dan fasilitas yang kurang dimanfaatkan, aspek materi yang kurang bervariasi dan aspek kesempatan yang sangat terbatas untuk melatih keterampilan menyimak.

Namun pada kenyataanya hambatan dan gangguan dialami oleh anak didik tertentu, sehingga mereka mengalami kesulitan dalam belajar. Dasarnya, pada tingkat tertentu memang ada anak didik yang dapat mengatasi kesulitan belajarnya tanpa harus melibatkan orang lain. Namun, pada kasus-kasus permasalahan tertentu, karena anak didik belum mampu mengatasi kesulitan belajarnya, maka bantuan guru atau orang lain dalam hal ini teman di kelas sangat diperlukan oleh anak didik (Fuad, 2019: 162)

Maka, dapat disimpulkan bahwa temuan di lapangan menunjukan bahwa kendala mahasiswa dalam mendengar dan berbicara bahasa Arab merupakan bagian dari dampak minimnya pemahaman, kurangnya praktik dan bisa juga dari minimnya motivasi untuk mengembangkan kemampuan berbicara dan mendengar. Karena, sebaian dari mereka lebih terfokus pada kosa kata dan kaidah tata bahasa Arab.

Beragam permasalahan yang terdapat pada pembelajaran bahasa Arab harus bisa dipecahkan, baik permasalahan tersebut dari guru maupun siswanya. Meskipun mata pelajaran bahasa Arab bukan satu-satunya faktor yang menentukan dalam pembentukan watak dan kepribadian siswa tersebut, namun secara subtansial dan harfiah, mata pelajaran bahasa Arab memiliki kontribusi dalam memberikan motivasi kepada siswa untuk memahami Alquran dan Hadits dengan harapan nantinya dapat mempraktekkan nilai-nilai keagamaan dan akhlaqul karimah, baik terhadap masyarakat maupun bangsa dan negara (Amirudin dan Fatmawati, 2018: 28)

b. Kendala aspek kemampuan membaca, menterjemahkan, dan menulis mahfüzhat

1) Membaca

Membaca merupakan keterampilan berbahasa tulis yang bersifat reseptif. Sebagai sebuah keterampilan, membaca memiliki tiga komponen kemampuan, yakni (1) pengenalan terhadap 


\section{Arabi : Journal of Arabic Studies}

aksara serta tanda baca, (2) korelasi aksara dan tanda baca dengan unsur-unsur linguistik yang formal, serta (3) korelasi antara aksara, tanda baca dan unsur linguistik formal dengan makna (Broughton dalam Sudaryat, 2015: 181).

Al-Fauzan (2011: 194) berpendapat bahwa membaca merupakan transformasi sistem kebahasaan dari simbol yang terlihat yakni huruf kepada makna atau maksud dari huruf itu. Sementara itu Effendy (2012: 166) mengatakan bahwa kemahiran membaca mengandung dua aspek atau pengertian. Pertama, mengubah lambang tulis menjadi bunyi. Kedua, menangkap arti dari seluruh situasi yang dilambangkan dengan lambang-lambang tulis dan bunyi tersebut. Simpulnya, kemahiran membaca terletak pada aspek yang kedua. Sedangkan aspek yang pertama mendasari kemahiran yang kedua. Yang akhirnya, keduanya saling keterkaitan.

Bagan 2 Kesulitan Membaca, Menulis dan Menterjemah

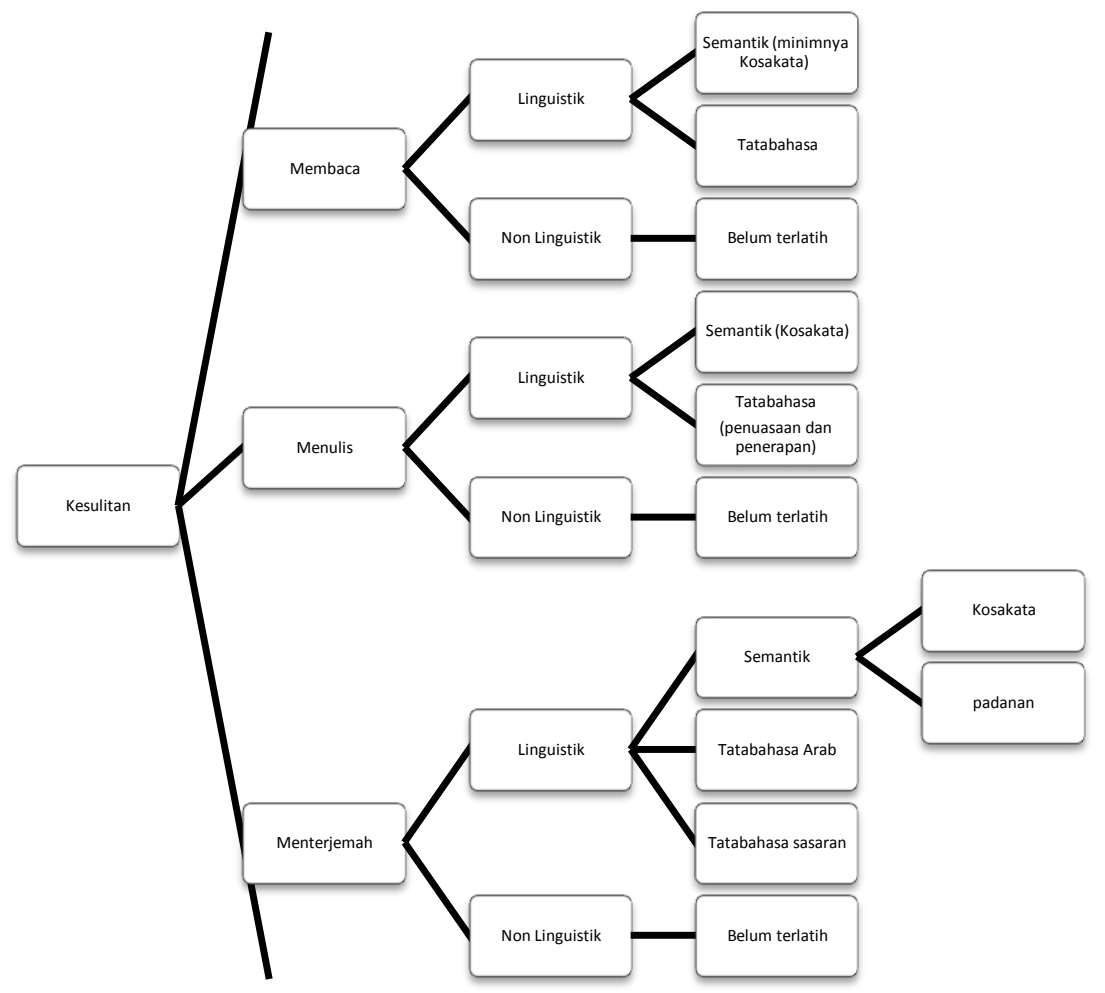

Sementara itu, kesulitan mahasiswa dalam kegiatan membaca menterjemahkan disebabkan oleh faktor linguistik baik faktor kompetensi maupun performansi. Kesulitan pada aspek kompetensi bahasa disebabkan oleh beberapa faktor: (1) semantik, pembendaharaan kosakata, memahami makna, dan istilah khusus; (2) tata bahasa, penguasaan aspek sintaksis dan morfologis; (3) penguasaan kedua bidang tersebut. Adapun kesulitan mahasiswa pada aspek performansi dalam kegiatan membaca menterjemahkan adalah (1) semantik, pemilihan padanan; (2) tatabahasa, menyusun kalimat dalam bahasa sasaran. Adapun upaya yang dilakukan yakni melalui belajar, latihan dan membuka kamus. Hal tersebut dibuktikan oleh data angket yaitu (90,48\%) mahasiswa memiliki kendala saat membaca dan menterjemah, dan $(11,90 \%)$ dari mahasiswa tidak mengalami kendala dalam hal itu.

Berdasarkan pernyataan di atas, diketahui bahwa kemampuan membaca terdapat beberapa masalah tata bahasa, yakni penguasaan aspek sintaksis dan morfologi, hal ini difungsikan sebagai dasar untuk pengenalan dan koreksi tanda baca pada bahasa taget. Namun tidak semua pembelajar memahami dengan baik seluruh aspek tersebut. Adapun aspek linguistik formal dan makna yakni minimnya pembendaharaan kosa kata dan istilah khusus. 


\section{Problem non kebahasaan untuk memahami mahfuzhat}

Adapun temuan yang terkait dengan kesulitan mahasiswa dari aspek non kebahasaan terdiri dari beberapa asepek meliputi aspek internal, sistem, dan pengaruh luar mencakup lingkungan. (1) aspek internal meliputi (a) komitmen terhadap diri sendiri untuk praktik; (b) manajemen waktu; (c) kurangnya motivasi; (d) faktor fisik yakni lelah. (e) memori dan kognisi meliputi daya hapal dan memahami materi; (f) malas; (g) masalah percaya diri; (h) minder. Faktor yang kedua (2) faktor sistem meliputi (a) aturan, yaitu ketegasan untuk praktik masih kurang; (b) pengelolaan waktu yaitu jadwal padat; (c) mahasiswa terlalu banyak. Yang ketiga (3) yakni faktor luar meliputi (a) pengaruh teman bisa berdampak negatif, seperti malas; (b) kurangnya kerjasama antar sesama rekan; (c) terkait metode; (d) dan menganggap semua mahasiswa sudah bisa.

Dewasa ini, kita memahami bahwa siswa merupakan individu yang sedang berkembang, tentunya sama dalam pemerolehan bahasa kedua, terdapat beberapa faktor penyebab kesulitan. berbeda ketika mereka mempelajari bahasa pertama atau bahasa ibu. Mar'at $(2005,94-96)$ dan Chaer (2009: 250-254) menjabarkan di bawah ini beberapa kesulitan pembelajaran bahasa kedua, yaitu:

\section{Waktu yang digunakan}

Waktu yang digunakan atau kesempatan untuk berbahasa relatif kurang, atau lingkungan bahasa sama sekali tidak ada. Kondisi perkuliahan hanya terbatas untuk mendukung kegiatan waktu berbahasa, waktu berbahasa dalam hal ini berbahasa Arab hanya digunakan dan dilakukan ketika jam perkuliahan atau waktu kuliah aktif, sedangkan waktu selepas perkuliahan kurang mendukung. Hal ini menjadi motivasi bagi kegiatan kemahasiswaan untuk melakukan tinjauan dan penyediaan waktu berbahasa.

waktu yang tersedia dalam perkuliahan pula tidak serta merta hanya mewadahi berbahasa lisan, namun juga berbahasa tulisan. Hal ini membutuhkan pendampingan dalam telaah pemahaman berbahasa, hal ini juga menyebabkan waktu semakin terbagi selain untuk praktek berbahasa.

Kondisi lainnya yaitu dari manajemen waktu mahasiswa, perkuliahan Mahfuzhat dilakukan di jenjang tingkat awal perkuliahan, pengelolaan manajamen waktu dari mahasiswa tersebut untuk membagi waktu tugas, menghafal, dan belajar masih perlu bimbingan. Waktu banyak dihabiskan untuk fpkus menyusun atau membuat tugas-tugas perkuliahan yang lain, hal ini kerap menjadi alasan ketika jam atau waktu menghafal kurang. Faktor lain adalah bagi mahasiswa yang baru pertama kali belajar bahasa Arab, waktu yang dibutuhkan semakin lama, dan waktu bimbingan pula semakin ditambah. Hal ini yang menjadi rujukan bagi manajamen program studi menyusun kegiatan yang dapat mengalokasikan waktu penunjang dalam hal ini pembelajaran mahfuzhat bisa dapat dilakukan secara efektif dan efesien.

\section{Masalah peranan pengajar}

Masih minimnya pengajar bahasa asing (Arab) kemampuan relatif kurang dalam hal berbicara (Mall, M.A. 2002: 52). Kehadiran pengajar asli penutur menunjang dalam keberlangsungan pembelajaran mahfuzhat. Peranan pengajar bahasa asing dalam hal ini asli penutur memudahkan dalam pembelajaran, hal ini disebabkan karena penguasaan bahasa, budaya, dan karakteristik bahasa dan budaya dari bahasa target dalam hal ini bahasa Arab lebih dikuasai. Sayangnya, kehadiran pengajar asli penutur sangat terbatas, juga waktu pembelajaran bersama pengajar asli penutur juga terbatas.

Di samping itu, pengajar non penutur memiliki peranan lebih dalam pembelajaran, motivasi dan keahlian yang dimiliki seperti keahlian komunikasi lisan atau tertulis, juga kemampuan persuasif dengan menggunakan bahasa ibu dalam hal ini bahasa Indonesia memudahkan untuk dimengerti mahasiswa. Sayangnya, penggunaan bahasa yang disampaikan pengajar non penutur cenderung tercampur dan sering menggunakan bahasa Indonesia sebagai bahasa Ibu, di samping 


\section{Arabi : Journal of Arabic Studies}

menggunakan bahasa Arab sebagai bahasa target. Hal ini secara tidak langsung menyebabkan kurangnya berlatih dan terbiasa untuk membiasakan berbahasa bagi mahasiswa.

Masalah peranan pengajar asli penutur dan non penutur masih menjadi salah satu aspek non kebahasaan yang mempengaruhi pembelajaran Mahfuzhat. Hal ini menjadi rujukan sebagai evaluasi bagi setiap pengajar baik asli penutur atau non penutur untuk mengoptimalkan kemampuan dan keahlian dari kompetensi kebahasaan yang dimiliki untuk secara tepat disampaikan kepada mahasiswa dalam pembelajaran.

\section{Interferensi}

Permasalahan lain, semisal bahasa asing yang dipelajari itu memiliki lebih banyak fonemfonem yang tidak dimiliki oleh bahasa pertama. Maka, kesulitan yang timbul pada umumnya yaitu kesulitan dalam pelafalan fonem-fonem bahasa kedua atau bahasa asing yang dipelajari tersebut. Kesulitan ini diakibatkan oleh perbedaan berbagai fonem kedua bahasa tersebut, baik dari sisi cara maupun posisi artikulasi. Kesulitan-kesulitan yang muncul itu berupa kesalahan pelafalan berbagai ragam fonem bahasa kedua/asing yang dipelajari yang selanjutnya akan membawa dampak yang sangat buruk jika tidak diajarkan dengan baik kepada pembelajar bahasa kedua/asing (Sanusi, Y. B, 2005: 2).

Kesalahan pelafalan berbagai fonem bahasa kedua/asing itu berdampak terhadap keliruan makna. Kesalahan pelafalan dari para pelajar bahasa kedua atau bahasa asing berdampak pada keadaan di mana membingungkan lawan bicaranya khususnya lawan bicara penutur asli. Kesalahan makna dan kesalahan interpretasi ini berkaibat terhadap alur komunikasi yang tidak dapat berjalan dengan baik (Sanusi, Y. B, 2005: 2; Emil, F.J. 1981: 125)

\section{Motivasi}

Motivasi sangat menentukan keberhasilah belajar, menurut teori belajar motivasi merupakan kekuatan mental yang menjadi penggerak belajar (Dimyati dan Nudjiono, 2002: 51). Bila motivasi kurang maka keberhasilan belajar siswa menjadi kurang maksimal. Sementara Gardner di dalam (Chaer dan Agustina, 2009: 251; Santoso, A, 2007: 5) motivasi mempelajari bahasa asing sangat berpengaruh, khususnya faktor sosial-kutural dari pembelajar, motivasi mempelajari bahasa asing mempunyai dua fungsi:

1) Fungsi integratif yaitu motivasi yang mendorong seseorang mempelajari bahasa asing disebabkan keinginan untuk berkomunikasi dengan penutur asli dari bahasa yang sedang dipelajari, dan ingin menjadi masyarakat atau anggota penutur bahasa tersebut.

2) Fungsi instrumenal yaitu motivasi yang mendorong seseorang untuk memiliki kemauan untuk mempelajari bahasa asing, disebabkan motivasi dari sebuah tujuan yang bermanfaat, seperti ingin memperoleh pekerjaan sebagai mobilitas sosial pada lapisan masyarakat tersebut.

Lalu Teh dan Embi (2009: 11) menuturkan hasil kajiannya yaitu bahwa pelajar yang termotivasi akan cenderung menggunakan lebih banyak strategi dibandingkan dengan pelajar yang kurang memiliki motivasi. Pelajar yang memiliki motivasi yang tinggi lebih banyak menggunakan strategi latihan terkait peraturan formal (seperti menganalisa perkataan, membandingkan bahasa ibu dengan sasaran, dan melihat pola bahasa), latihan fungsi (seperti menyertai program dalam bahasa sasaran, dan berbicara dengan diri sendiri dalam bahasa sasaran), pembelajaran umum (seperti mengelak daripada menghafal, dan berusaha dengan tekun), dan pemerolehan input perbualan (seperti meminta dibetulkan sebutan, dan penumpukan kepada bahasa badan untuk mengumpul maklumat semasa perbualan).

Kemudian, berdasarkan hasil penelitian yang dilakukan oleh Ghani. K.A. (2008: 3) diperoleh interpretasi kajian penelitian, adapun kajian penelitian tersebut menunjukkan: (a) Tahap motivasi pembelajaran kemahiran menyimak berada pada tahap tinggi, (b) Tahap pencapaian kemahiran menyimak bahasa Arab pada tahap sederhana, (c) Terdapat korelasi yang signifikan antara 
motivasi dan pencapaian kemahiran menyimak bahasa Arab, dan (d) Terdapat perbedaan yang signifikan antara tiga kumpulan motivasi pembelajaran.

\section{Faktor usia}

Mengingat mereka (siwa/ mahasiswa) merupakan individu yang sedang menjalani proses perkembangan, dengan rentang usia antara 18-24 tahun termasuk kategori dewasa. Ada beberapa anggapan serta hipotesis yang dikemukakn oleh para ahli, Savignon di dalam (Sadtono, 1987: 66) menyatakan di dalam penelitiannya bahwa para siswa yang diberi kesempatan untuk berbicara mulai dari pelajaran pertama dalam belajar bahasa asing memiliki prestasi yang jauh lebih baik dari mereka yang mempelajari bahasa tanpa adanya penutur asli.

Terdapat beragam argumen yang menjelaskan bahwa pada dasarnya aspek biologis, kognitif, dan afektif merupakan penunjang kemahiran berbahasa. Sebagian dari mereka yaitu Penfield dan Roberts yang mendukung argumen biologis, lalu Rosansky dan Krasen yang mendukung argumen kognitif, selanjutnya Taylor dan Schuman yang mendukung argumen afeksi (Chaer, 2009: 252).

Namun dari segi usia, ada bebrapa aspek yang menjadi penyebab keslitan pembelajaran bahasa asing khususnya berbicara, yang dikutip dari (Mar'at, 2005: 96) di antaranya:

1) Usia lebih dari 12 tahun sistem motorik akan mengalami kesulitan dalam hal mengadaptasi bahasa asing (B2), Logat bahasa pertama tidak mudah hilang (B1).

2) Adanya anomia atau rasa kurang percaya diri, anomia atau rasa kurang percaya diri yang biasanya dilakukan oleh orang-orang dewasa.

3) Hubungan Neurofisiologi dari otak, otak orang dewasa yang berumur lebih dari 12 tahun atau mereka yang telah mengalami pubertasi yang cendrung kaku karena struktur otak telah mengalami pemelahan (laterisasi) pembagian fungsi kerja otak. Maka otak mereka tidak selent ur masa sebelumnnya.

4) Fungsi kongnitif, usia setelah 12 tahun konseptual sistem sudah berkembang sedemikian rupa, hal ini merupakan inti dari penggunaan bahasa yang mampu mengobservasi aturanat uran. Mereka yang masih belajar serta pemerolehan B2 yang masih terbatas akan cendrung segan melakukan latihan dan lain halnya dengan mereka yang berusia sebelunnya.

\section{Faktor Penyajian Formal}

Pembelajaran bahasa asing khususnya bahasa Arab yang dipelajari di sekolah serta di pesantren sebagian banyak menggunakan model pembelajaran bahasa secara formal. Dikatakan formal karena banyak aspek yang terlibat dalam kegiatan tersebut, seperti guru, media, kurukulum, bahan ajar, dan instrumen yang lainnya. Aspek-aspek tersebut memilii pengaruh terhadap kecepatan dan keberhasilan belajar bahasa kedua dalam hal ini yakni bahasa Arab, dikarenakan berbagai faktor serta variabel yang telah disiapkan terlebih dahulu (Chaer, 2009: 252). Singkatnya, penyajian formal pembelajaran merupakan rekayasa untuk mencapai kompetensi yang diharapkan yang terjadi di lingkungan sekolah, sedangkan non-formal atau alami belajar bahasa di tempat atau negara penut ur bahasa tersebut, dan bisa dikatakana total immersion.

Mengacu pada kesulitan non kebahasaan yang dialami mahasiswa bisa disebabkan oleh beberapa faktor. Menurut Mar'at, (2005: 94-96); Chaer, A. (2009: 250-254); dan Mall, M.A. (2002: 52) faktor kemunculan anomia atau dimaknai rasa kurang percaya diri, biasanya dilakukan oleh orang-orang dewasa. Hal ini akan memunculkan perasaan minder, kurang percaya diri, malas, kurang motivasi, dan komitmen. Selanjutnya, aspek neurologi yang berdampak pada memori dan kognisi meliputi daya hapal dan memahami materi. Hal lain yakni faktor terkait sistem tdengan cara atau nilai yang dianut di dalam lingkungan tertentu. Namun, faktor individu, kompetensi, latar belakang pendidikan terdapat perbedaan kesulitan mahasiswa dari kelas kemahiran bahasa sangat baik sudah tidak mengalami masalah dengan aspek materi, kesulitan lebih ke minimnya penyediaan buku sumber serta tugas dalam membantu rekannya. Lain halnya dengan siswa pada kemahiran menengah disebabkan oleh beberapa aspek terkait dengan lingkungan, waktu, dan 


\section{Arabi : Journal of Arabic Studies}

belum terbiasa berbahasa. Hal ini disebabkan oleh faktor pribadi, kompetensi dan latar belakang pendidikan. Berbeda dengan siswa pada kelas kemahiran bahasa yang masih kurang mengalami kesulitan lebih banyak yaitu aspek dasar.

\section{Solusi yang perlu dilakukan untuk mengatasi problemtika pembelajaran mahfuzhat}

Peningkatan kemampuan mahasiswa baik praktik atau pemahaman mahfuzhat bisa dilakukan dengan melalui beberapa cara:

\section{a. Motivasi}

Motivasi dapat dimaknai dengan penjelaan dorongan yang timbul pada diri seseorang secara sadar atau tidak sadar untuk melakukan suatu tindakan dengan tujuan tertentu. Adapun secara spesifik, motivasi di dalam bidang prikologi adalah usaha yang dapat menyebabkan seseorang atau kelompok orang tertentu tergerak melakukan sesuatu karena ingin mencapai tujuan yang dikehendakinya atau mendapat kepuasan dengan perbuatannya (KBBI, 2008).

Motivasi sangat menentukan keberhasilah belajar, menurut teori belajar motivasi merupakan kekuatan mental yang menjadi penggerak belajar (Dimyati dan Nudjiono, 2002: 51). Bila motivasi kurang maka keberhasilan belajar siswa menjadi kurang maksimal. Sementara Gardner di dalam (Chaer dan Agustina, 2009: 251; Santoso, A, 2007: 5) motivasi mempelajari bahasa asing sangat berpengaruh, khususnya faktor sosial-kutural dari pembelajar, motivasi pembelajar dalam mempelajari bahasa asing mempunyai dua fungsi integratif dan instrumenal.

Sementara itu, berdasarkan temuan di lapangan, motivasi mahasiswa mempelajari bahasa Arab adalah 1) fungsi integrasi yakni ingin fasih berbahasa Arab; 2) instrumenal, yakni karena bidang studi, ingin bisa menterjemahkan, memperdalam Islam dan memahami kandungan alQur'an serta keunikan dan karakteristik bahasa Arab itu sendiri. Lalu, adapun pernyataan lain mengenai minimnya motivasi terhadap bahasa Arab adalah 1) lemahnya motivasi dan 2) masih lebih berminat terhadap bidang lain.

Berdasarkan kajian hasil penelitian yang dilakukan Oleh Ghani. K.A. (2008: 3). Kajian tersebut menjelaskab: (a) tahap motivasi pembelajaran kemahiran menyimak berada pada tahap tinggi, (b) tahap pencapaian kemahiran menyimak bahasa Arab pada tahap sederhana, (3) terdapat korelasi signifikan antara motivasi dan pencapaian kemahiran mendengar bahasa Arab, dan (d) terdapat perbedaan yang signifikan antara tiga kumpulan motivasi pembelajaran. Data hasil temuan penelitian di lapangan menunjukan bahwa $(75,00 \%)$ memiliki motivasi untuk tujuan instrumenal seperti bidang studi, ingin bisa menterjemahkan, memperdalam Islam dan memahai kandungan Alquran serta keunikan dan karakteristik bahasa Arab itu sendiri.

\section{b. Menumbuhkan Rasa Percaya Diri}

Tidak abisa dilepaskan, bahwa pengajaran dan pembelajaran berkaitan dengan latar belakang mahasiswa, dalam pembelajaran bahasa arab tidak semua mahasiswa mempuyai latar belakang bahasa Arab. Sedangkan secara teori, salah satu faktor pendukung keberhasilan suatu pembelajaran adalah keserasian atau keselarasan disiplin ilmu yang ditempuh, namun demikian tidaklah semua mahasiswa dapat menempuh pendidikan yang sesuai dengan latar belakang pendidikanya ketika sekolah menengah (Sarbaini, A, 2018: 182).

Kajian hasil temuan di lapangan menunjukan bahwa masalah percaya diri mahasiswa disebabkan oleh beberapa faktor, pertama: minimnya penguasaaan bidang ilmu kebahasaan yakni, takut salah dalam pelafalan (fonologis), takut salah dalam kaidah (sintaksis dan morfologi), dan kurangnya pembendaharaan kosakata (semantik). Kedua, aspek internal dan psiskologis mahasiswa seperti takut salah dan minder. Ketiga, konteks berbahasa Arab yang menjadikan mahasiswa tidak percaya diri adalah a) berbicara di depan umum, b) mendapat pertanyaan langsung dari dosen, c) berbicara dengan lawan tutur yang lebih mahir. Kemudian dapat disimpulkan bahwa minimnya pemahaman dan kurangnya latihan menjadikan mahasiswa mengalami masalah percaya diri dalam bahasa Arab hal itu berdapak pada rasa minder, takut salah, dan gugup. 
Terdapat beberapa faktor yang mempengaruhi percaya diri mahasiswa dalam berbahasa Arab. Mengingat mereka merupakan individu yang sedang menjalani proses perkembangan, dengan rentang usia antara 18-24 tahun termasuk kategori dewasa. Ada beberapa anggapan serta hipotesis yang dikemukakn oleh para ahli, Savignon di dalam (Sadtono, 1987: 66) menyatakan di dalam penelitiannya bahwa para siswa yang diberi kesempatan untuk berbicara mulai dari pelajaran pertama dalam belajar bahasa asing memiliki prestasi yang jauh lebih baik dari mereka yang mempelajari bahasa tanpa adanya penutur asli. Kemudian, ada beberapa argumen yang menyatakan bahwa aspek biologis, kognitif, dan afektif adalah penunjang kemahiran berbahasa. Seperti Penfield dan Roberts yang mendukung argumen biologis, lalu Rosansky dan Krasen yang mendukung argumen kognitif, lalu Taylor dan Schuman untuk argumen afeksi (Chaer, 2009: 252).

Selain itu, faktor aspek waktu juga menjadi tolok ukur munculnya percaya diri, apabila waktu yang telah digunakan atau kesempatan untuk berbahasa relatif kurang, atau lingkungan bahasa sama sekali tidak ada maka akan mempersulit berkembangnya kepercayaan diri (Mar'at, 2005: 94-96; Chaer, 2009: 250-254). Temuan lain menunjukan bahwa berdasarkan hasil wawancara dengan mahasiswa JS yang berada pada kelas kemahiran sangat baik, meskipun memiliki pemahaman baik namun perlu waktu dua bulan untuk berani dan percaya diri berbahasa Arab dan masalah tersebut disebabkan kurangnnya tuntuan dan aplikasi, namun mahasiswa kelas kemahiran menengah dan rendah masih mengalama kendala pada aspek penerapan dan aspek mikro linguistik yakni semantik dan tatabahasa.

Kemudian, adapun upaya mengatasi yang dilakukan tim dosen dalam menangani masalah percaya diri mahasiswa untuk praktik bahasa Arab dilakukan dengan dua pola (1) kegiatan terprogram yaitu melalui kegiatan pembelajaran a) tampil ke depan, kemudian b) khutbah qashirah, mahasiswa diwajibkan untuk ceramah singkat di mushala yang dilakukan selepas magrib. Kemudian (2) melalui interaksi berbahasa Arab pada kegiatan yang terkait dengan kesekretariatan seperti meminta ijin yang memaksa mahasiswa untuk berbahasa Arab.

\section{Simpulan}

Berdasarkan penjelasan hasil dan pembahasan dapat disimpulkan bahwa kesulitan dan hambatan pada aspek kebahasaan untuk memahami mahfûzhat adalah performansi disebabkan oleh minimnya waktu atau intensitas untuk praktik berbahasa seperti minimnya intesitas waktu praktik empat kemahiran berbahasa, penggunaan idiom dan menterjemah.

Adapun temuan yang terkait dengan kesulitan mahasiswa dari aspek non kebahasaan terdiri dari beberapa aspek meliputi aspek internal, sistem, dan pengaruh luar mencakup lingkungan. (1) aspek internal meliputi (a) komitmen terhadap diri sendiri untuk praktik; (b) manajemen waktu; (c) kurangnya motivasi; (d) faktor fisik yakni lelah. (e) memori dan kognisi meliputi daya hapal dan memahami materi; (f) malas; (g) masalah percaya diri; (h) minder. Faktor yang kedua (2) faktor sistem meliputi (a) aturan, yaitu ketegasan untuk praktik masih kurang; (b) pengelolaan waktu yaitu jadwal padat; (c) mahasiswa terlalu banyak. Yang ketiga (3) yakni faktor luar meliputi (a) pengaruh teman bisa berdampak negatif, seperti malas; (b) kurangnya kerjasama antar sesama rekan; (c) terkait metode; (d) dan menganggap semua mahasiswa sudah bisa.

Problem non kebahasaan untuk memahami mahfûzhat disimpulkan terdiri dari beberapa faktor seperti pengajar, metode yang disajikan, media, materi, faktor eksternal dan internal dari pembelajar. Serta peningkatan komponen pembelajaran serta implementasi pembelajaran, solusi yang perlu dilakukan untuk mengatasi problemtika pembelajaran mahfûzhat adalah dengan cara memberi motivasi kepada pembelajar [] 
Arabi : Journal of Arabic Studies

\section{References}

al-Fauzan, A. 2011. Idhaat li Mualimi al-Lughah al-Arabiyah li ghair al-Nathiqin biha. Riyadh: al'Arabiyah li al-Jami'.

Amirudin \& Fatmawati. 2018. "Problematika Pembelajaran Bahasa Arab pada Siswa kelas VIII SMP Unismuh Makassar”, Al-Maraji Jurnal Pendidikan Bahasa Arab, Vol. 2, No. 2.

Anzar, Safni. \& Mardhatillah. 2017. "Analisis Kesulitan Belajar Siswa pada Pembelajaran Bahasa Indonesia di Kelas V SD Negeri 20 Meulaboh Kab. Aceh Barat Tahun Ajaran 2015/2016”, Bina Gogik, Vol. 4, No. 1.

Azhar, M. 2005. "Beberapa Aspek Keunikan dan Keistimewaan Bahasa Arab sebagai Bahasa alQur'an”, Jurnal Teknologi UKM, Vol. 42.

Chaer, A. \& Agustina L. 2006. Sosiolinguistik Perkenalan Awal. Jakarta: Rineka Cipta.

Chaer, A. 2007. Linguistik Umum. Jakarta: Rineka Cipta.

Chaer, A. 2009. Psikolinguistik Kajian Teoritik. Jakarta: Rineka Cipta.

Dimyati. \& Mudjiono. 2002. Belajar dan Pembelajaran. Jakarta: Rineka Cipta.

Effendy, Ahmad Fuad. 2012. Metodologi Pengajaran Bahasa Arab. Malang: Misykat.

Emil, F.J. 1981. “Cross-Language Phonetic Interference Arabic to English”, Language and Speech, Vol. 24, No. 2.

Fahrurrozi, Aziz. \& Erta Mahyuddin. 2012.Teknik Pembelajaran Bahasa Arab. Bandung: Pustaka Cendekia Utama.

Fahrurrozi, Aziz. 2014. "Pembelajaran Bahasa Arab: Problematika dan Solusinya", Arabiyat: Jurnal Pendidikan Bahasa Arab dan Kebahasaaraban, Vol. 1, No. 2.

Faiqah, Nurul. 2017. "Manajemen Pembelajaran Bahasa Arab di Sekolah”, Jurnal At-Tafkir, Vol. 10, No. 1.

Faruqi. 2006. Atlas Budaya Islam. Bandung: Mizan.

Fuad, Faturahman. 2019. “Analisis Kesulitan Belajar Bahasa Arab”, Al-Lisan Jurnal Bahasa, Vol. 5, No. 2.

Ghani. K.A. 2008. "Motivasi Pembelajaran Kemahiran Mendengar Bahasa Arab dan Hubugannya dengan Pencapaian Pelajar", Jurnal Pendidikan, Vol. 33.

Gade, Fihrani. 2014. "Implementasi Metode Takrar dalam Pembelajaran Menghafal Alquran”, Jurnal Ilmiah Didaktika, Vol. 14, No. 2.

Hizbullah, N. \& Mardiah, Z. 2014. "Masalah Pengajaran Bahasa Arab di Madrasah Aliyah di Jakarta", Jurnal Al-Azhar Indonesia Seri Humaniora, Vol. 2, No. 3.

Kosim, N. et al. 2020. "Pembelajaran Bahasa Arab Melalui Daring: Problematika, Solusi, dan Harapan”, Arabiyat: Jurnal Pendidikan Bahasa Arab dan Kebahasaaraban, Vol. 1, No. 2.

Mall, M.A. 2002. "The Problem experienced With The Teaching of Arabic to Learners in Muslim Private Schools in South Africa and Botswana", Per Linguam, Vol. 17, No. 2.

Mar'at, S. 2005. Psikolinguistik Suatu Pengantar. Bandung: Refika Aditama.

Nandang, A. \& Sanusi, H. 2019. “Arab Language Learning Management in Pesantren”, Al-Hizam, Vol. 4, No. 1.

Nurhidayati, Anin. 2006. Diktat Metodologi Pengajaran Bahasa Arab. Tulungagung: STAIN Tulungagung.

Vol. 5 No. 2 |214-215

Copyright ( 2020 | ARABI | p-ISSN 2548-6616 | e-ISSN 2548-6624 
Omari, J. 2008. Understanding the Arabic Culture "A Practical Cross-Cultural Guide to Working in the Arab world. United Kingdom: Spring Hill House.

Othoman, A.O. 2013. "An Analysis of the Role of Micro and Level in Rendering Some Standard Arabic Proverb into English”, Unpublished Disertation, University of Leeds.

Rahmawati, Ana. \& Laila, Nor Azizah. 2019. "Model Pembelajaran Bahasa Arab di SMPUT Bumi Kartini dalam Meningkatkan Kemampuan Siswa Berbahasa Arab”, Jurnal Al-Fikri, Vol. 2, No. 2.

Sadtono, E. 1987. Pengajaran Bahasa Asing Khususnya Bahasa Inggris. Jakarta: P2LPTK.

Santoso, A. 2007. "Ilmu Bahasa dalam Perspektif Kajian Budaya", Bahasa dan Seni, Vol. 35, No. 1.

Sanusi, Y. B. 2005. "Efektivitas Formal Inntruction dalan Peningkatan Kemampuan Mahasiswa Melafalkan Fonem-Fonem Frikatif Bahasa Arab", Bahasa dan Seni, Vol. 33, No. 1.

Sarbaini, Albarra. 2018. "Problematika Pengajaran Bahasa Arab Mahasiswa Lulusan Umum di Prodi PBA Jurusan Tarbiyah STAIN Jurai Siwo Metro 2016”, Jurnal An-Nabighah, Vol. 20, No. 2.

Shereen, M. S. 2008. "The Relationship between Vocabulary Knowledge and Reading Comprehension of Authentic Arabic Texts", Unpublished Thesis, Brigham Young University.

Sudaryat, Y. 2015. Metdodologi Pembelajaran (Aplikasinya dalam Pembelajaran Bahasa dan Sastra). Bandung: Sekolah Pascasarjana UPI Bandung.

Supriono, Iwan Agus. \& Rusdiani, Atik. 2019. "Implementasi Kegiatan Menghafal Alquran Siswa di LPTQ Kabupaten Siak”, Jurnal ISEMA, Vol. 4, No. 1.

Tajuddin, S. 2017. "Pengembangan Model Pembelajaran Bahasa Arab Tingkat Sekolah Dasar untuk Meningkatkan Kemampuan Berbahasa Arab Siswa”, Jurnal Parameter, Vol. 29, No. 2.

Teh, K.S.M. dan Embi, M.A. 2009. "Korelasi Stategi dengan Motivasi dalam Pembelajaran Bahasa Arab", Jurnal Pendidik dan Pendidikan, Vol. 24.

Tim Penyusun. 2008. Kamus Besar Bahasa Indonesia. Jakarta: Balai Pustaka.

Vadhillah, S. et al. 2016. "Problematika Pembelajaran Bahasa Arab di MAN Batu Mandi Tilatang Kamang", Arabia, Vol. 8, No. 1.

Wahida, Besse. 2017. "Problematika Pembelajaran Bahasa Arab (Studi Kasus terhadap Problematika Metodologis Pembelajaran Bahasa Arab di IAIN Pontianak", Jurnal Al-Atsar, Vol. 7, No. 1. 